\title{
Antimicrobial activity of amazonian medicinal plants
}

Amanda A Oliveira', Jorge FO Segovia², Vespasiano YK Sousa', Elida CG Mata', Magda CA Gonçalves³, Roberto M Bezerra ${ }^{4}$, Paulo OM Junior ${ }^{1}$ and Luís IB Kanzaki ${ }^{*}$

\begin{abstract}
Objectives: The aqueous extracts of currently utilized Amazonian medicinal plants were assayed in vitro searching for antimicrobial activity against human and animal pathogenic microorganisms.

Methods: Medium resuspended lyophilized aqueous extracts of different organs of Amazonian medicinal plants were assayed by in vitro screening for antimicrobial activity. ATCC and standardized microorganisms obtained from Oswaldo Cruz Foundation/Brazil were individually and homogeneously grown in agar plate, and holes previously perforated in the gel were filled with diluted plant aqueous extracts. Inhibition halos were evaluated and controlled by the use of the fluoroquinolone ciprofloxacin.

Results: The Amazonian medicinal plants, Hymenelobium petraeum showed inhibitory activity over Staphylococcus aureus, Enterococcus faecalis, Salmonella enterica serovar Typhi, Acinetobacter baumannii and Candida albicans, while Vatairea guianensis and Symphonia globulifera presented inhibitory activity exclusively for Staphylococcus aureus.

Also, Ptychopetalum olacoides and Pentaclethra macroloba inhibited the growth of Klebsiella ozaenae and Acinetobacter baumannii.

Conclusion: The aqueous botanic extracts that showed activity against microroganisms of ATTC and Osvaldo Cruz strains had at least $40 \%$ of antimicrobial activity when compared to halo inhibition produced by the commercial antibiotic ciprofloxacin utilized as a control. Of all plants extracts assayed, the Hymenelobium petraeum had the best performance, sometimes exhibiting higher activity than ciprofloxacin. It is not well-defined by the physicians the exact indication of the majority of medicinal plants in the Amazon area in Brazil. Natives utilize the plants according to their symptoms, based on the traditional knowledge transmitted orally from generation to generation, among Amerindians, Afrodescendents and ethnic mixed populations. A significant number of Amazonian medicinal plants are totally unknown related to their medicinal properties including mechanism of action and therapeutic effects, as very few information is reported in the scientific literature. A tiny amount of data is presented, as the preliminary antimicrobial properties of the medicinal plants here accessed, under the urgent necessity of new antibiotics in the market and in face of the increased resistance of infectious microorganisms to antimicrobials.
\end{abstract}

Keywords: Antimicrobials; Environment; Medicinal plants; Metabolites; Amazon

\footnotetext{
*Correspondence: kanzaki@unb.br

'Laboratory of Bioprospection, University of Brasília, University Campus Darcy

Ribeiro, Asa Norte, Brasília, DF, Brazil

Full list of author information is available at the end of the article
}

\section{国 Springer}

(c) 2013 Oliveira et al.; licensee Springer. This is an Open Access article distributed under the terms of the Creative Commons Attribution License (http://creativecommons.org/licenses/by/2.0), which permits unrestricted use, distribution, and reproduction in any medium, provided the original work is properly cited. 


\section{Introduction}

Nowadays, an increasing number of infectious agents are becoming more resistant to commercial antimicrobial compounds (Hancock et al. 2012). The necessity to develop new drugs requires varied strategies, among them, the bioprospection of secondary metabolites produced by medicinal plants (Dionisi et al. 2012; BenkoIseppon and Crovella 2010).

It is a common sense that the extensive Amazonian biodiversity, scarcely explored the economic rationality, would yield uncouns opportunities to find plant species potentially secreting metabolites, exhibiting antimicrobial activity, among other medicinal properties (Vieira et al. 2008; Basso et al. 2005).

Despite the Amazonian biome be characterized by high humidity and temperature during all the year, encompassing the rain forest, the limits in the northern region, in the Amapa state, exhibit a transitional area consisting of the Guyana plateau, which enrich much more the biological and geographycal diversity of this area (Alves 2008; Brothwell 1967).

Previously, we corroborated the biological activity of many different medicinal plants collected in distinct geographical regions, in the Amapa state. The ethanolic extracts of Geissospermum argenteum, Uncaria guianensis, Brosimum acutifolium, Copaifera reticulate, Licania macrophylla, Ptycopetalum olacoides and Dalbergia subcymosa exhibited inhibitory activity against multiresistant and Staphylococcus aureus and Pseudomonas aeruginosa ATCC strains (Correia et al. 2008). Also, ethanolic extracts of Copaifera reticulata, Tabebuia serratifolia, Brosimum rubescens and Carapa guianensis inhibited the colony formation of gram positive bacilli of Bacillus gender and Pseudomonas aeruginosa, microorganisms isolated from biocorroded metallic structures in a hydroelectric power unit, in the Amapa state (Correia et al. 2010). In other work, we detected allelopathic activity of ethanolic botanical extracts of Stryphnodendron adstringens, Carapa guianensis and Ouratea hexasperma utilizing Lactuca sativa as the model organism in the assays (Bezerra et al. 2010). Phytochemical analysis of Manilkara huberi (Ducke) fam. Sapotaceae, autochthonous of Amapa state, detected the presence of alfa and beta-amiriyn compounds (Segovia et al. 2011). Among the species of the Fabaceae, Caesalpiniaceae, Olacaceae, Chrysobalanaceae, Apocynaceae, Rubiaceae and Clusiaceae families, collected in the Amapa state, we detected antiretroviral, and lymphoproliferative activity, and also cytotoxicity for lymphoma/leukemia derived cell lines (Mata 2011).

Here, we investigated the antimicrobial activity of medicinal plants, currently used by native amazonians to treat their ailments. Plants were collected in different areas of Amapa state, in the Amazon region of Brazil.

\section{Material and methods}

\section{Botanical aqueous extracts}

A total of 19 plants aqueous extracts of a collection from the Laboratory of Bioprospection, of medicinal plants collected in the Amapa state, encompassing the Fabaceae (members of Caesalpiniaceae subfamily), Rubiaceae, Ochnaceae, Apocynaceae and Clusiaceae families were utilized searching for biological activity. The provisional voucher number of the plants here studied are kept at the Brazilian Agricultural Research Corporation/EMBRAPA, until be definitely transferred to the herbarium of the Institute of Scientific and Technological Research of the Amapa State (IEPA), Brazil. The aqueous extracts were prepared as described in Mata (2011). Briefly, 100 grams of powdered botanical sample (leaves, bark or fruits) were added to $1 \mathrm{~L}$ of distilled water at $70^{\circ} \mathrm{C}$ and allowed to cool until reaching $40^{\circ} \mathrm{C}$ in a water bath. Sequentially, the solution was filtered in filter paper, frozen at $-20^{\circ} \mathrm{C}$ and lyophilized in a Liotop apparatus (Model 1202, Liobras, Brazil). Before use, lyophilized samples were diluted in RPMI 1640 incomplete medium (INLAB, Brazil) and utilized in concentration of $2.275 \mathrm{mg} / \mathrm{mL}$.

\section{ATCC and Oswaldo Cruz Foundation Pathogenic Microorganisms}

The antimicrobial activity was assayed utilizing two groups of well-known microorganisms. One group of ATCC gram negative, pathogenic strains: Escherichia coli 25922, Escherichia coli 35218, Salmonella enterica serovar Enteritidis 564, Salmonella enterica serovar Typhimurium 5190, Pseudomonas aeruginosa 27853 and ATCC gram positive, pathogenic strains: Staphylococcus aureus 25923 and Enterococcus faecalis 29212; another group, gram negative microorganisms from Oswaldo Cruz Institute Foundation: Escherichia coli 00219; Salmonella enterica serovar Typhi 0029; Acinetobacter baumannii 00143; Klebsiella ozaenae 0075, the gram positive Enterococcus faecalis 00531 and, the yeast Candida albicans 40006. The microorganisms were maintained in nutrient agar at $4^{\circ} \mathrm{C}$ until the assays were carried out. All samples were kindly donated by Dr. Ernesto Hofer from Oswaldo Cruz Foundation (FIOCRUZ), Rio de Janeiro, Brazil.

\section{Agar diffusion test}

In order to assess the inhibitory activity of the botanical aqueous extracts, $10 \mathrm{uL}$ of each cultured microorganism in $1 \times 10^{-3} \mathrm{UFC} / \mathrm{mL}$ was plated in Muller-Hinton agar, which was previously perforated yielding 1 central hole surrounded by 8 ones. In the central hole, $30 \mathrm{uL}$ of ciprofloxacin $(16.6 \mathrm{ug} / \mathrm{mL})$ were added, and in the surrounded holes, $30 \mathrm{uL}$ of each plant aqueous extract. Antimicrobial activity was assessed by the appearance 

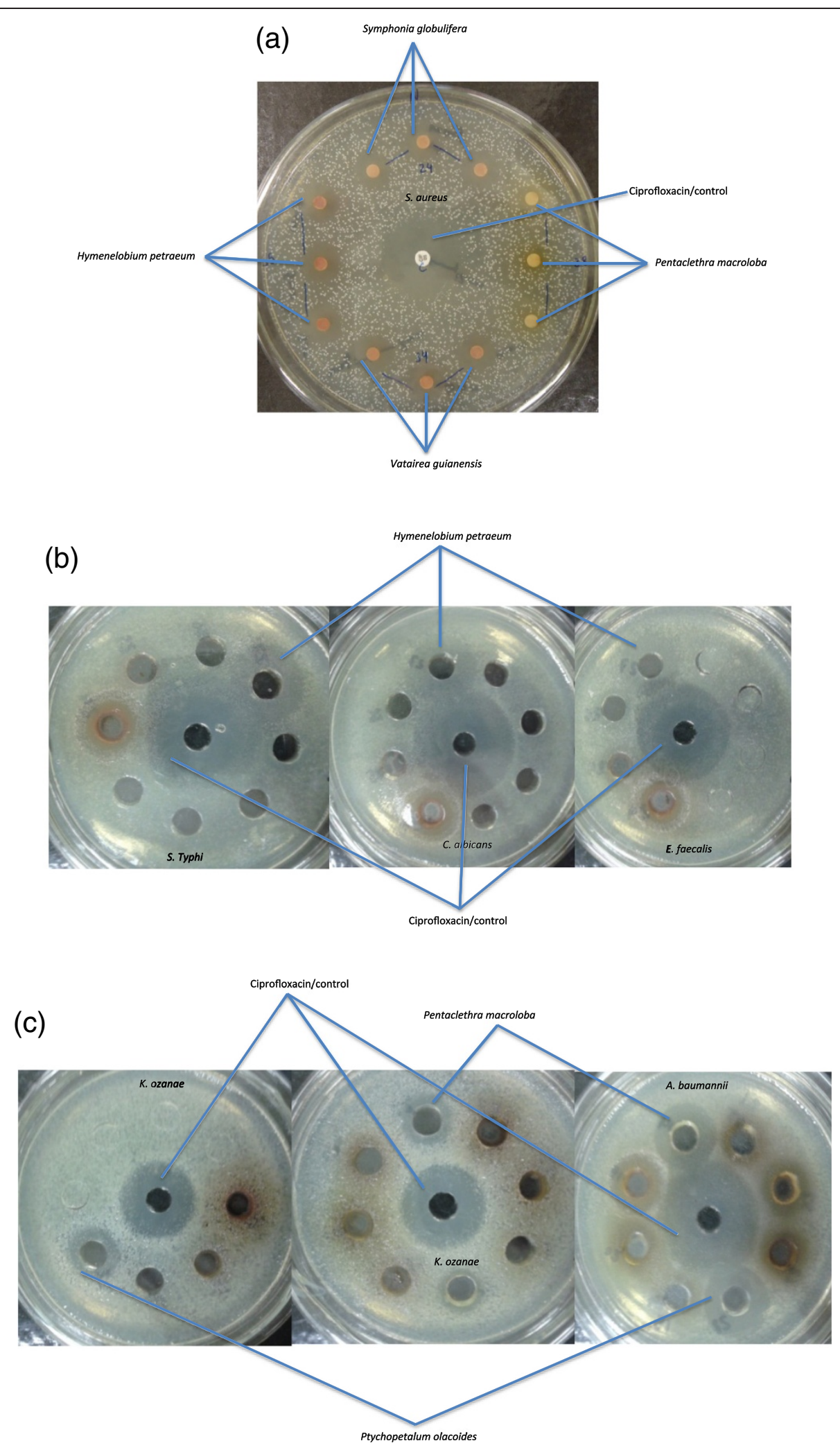

Figure 1 Antimicrobial activity of amazonian plants. (a) S. aureus inhibited by extracts of H. petraeum, S. globulifera and Vatairea guianensis (b) Inhibition of S. enterica serovar Typhi, C. albicans and E. faecalis by extract of H. petraeum (c) Extracts of $P$. olacoides and $P$. macroloba inhibited Klebsiella ozaenae and Acinetobacter baumannii. 
of inhibitory halo around the hole, without microbial growth.

\section{Results}

The botanical aqueous extract of Hymenelobium petraeum (provisional voucher number BRM54) inhibited the colony formation of Staphylococcus aureus ATCC 25923, Enterococcus faecalis ATCC 29212, Salmonella enterica serovar Typhi 0029 and Candida albicans, while the aqueous extracts of Vatairea guianensis (provisional voucher number BRM27) and Symphonia globulifera (provisional voucher number ESK71) were active against Staphylococcus aureus. Also, the aqueous extract of Ptychopetalum olacoides (provisional voucher number BRM08) and Pentaclethra macroloba (provisional voucher number BRM36) inhibited the growth of Klebsiella ozaenae and Acinetobacter baumannii. In all cases (Figure 1a, b and c), the botanical extract concentration utilized was $2.275 \mathrm{ug} / \mathrm{uL}$ and the initial inoculum of microorganisms was $1 \times 10^{-3} \mathrm{UFC} / \mathrm{mL}$ of ATCC bacterial strains and FIOCRUZ strains.

\section{Discussion}

Similar results to what is described in this study were found by (Araújo 2010), assaying ethanolic extracts of $V$. guianensis and S. globulifera, describing inhibitory activity over $S$. aureus colony's growth, obtained from human patients with oral mucositis. Furthermore, S. globulifera extract exhibited activity against the growth of all known species of Streptococcus gender and Candida albicans. In Dr. Duke's Phytochemical and Ethnobotanical Databases, $V$. guianensis is indicated for the treatment of ringworm and sore (Dr. Duke's Phytochemical and Ethnobotanical Databases. 2012. http://www.ars-grin.gov/ cgi-bin/duke/ethnobot.pl?Vatairea\%20guianensis), and S. globulifera for the treatment of headache and ulcer. There are not any data concerning the phytochemical analysis of Hymenelobium petraeum in the literature, except studies describing the plant anatomy and physiology (Oliveira et al. 2010). Here, we present the first report concerning the antimicrobial action of Ptychopetalum olacoides and Pentaclethra macroloba. The aphrodisiac properties of Ptychopetalum olacoides are well-known among native people in the Amazon forest. Based on these folk beliefs, some studies were carried out to investigate the biological activity of this plant in the nervous system, for the treatment of stress, sexual dysfunction and possibly Alzheimer disease (Mendes and Carlini 2007; Howes and Houghton 2012). Few studies describe the antihemorrhagic and antiproteolytic activity of Pentaclethra macroloba (da Silva et al. 2007).

Previously, we reported the antimicrobial activity of Dalbergia subcymosa, and now we confirm the biological property with other microorganisms (Correia et al. 2008). There is not any other published data about Dalbergia subcymosa.

Table 1 Halo measurement of antimicrobial activity of amazonian plant aqueous extracts

\begin{tabular}{llc}
\hline Botanical extract & Gram positive bacteria & $\begin{array}{c}\text { Median and Standard } \\
\text { deviation (halo size) }\end{array}$ \\
\hline $\begin{array}{l}\text { Symphonia globulifera } \\
\text { Vatairea guianensis }\end{array}$ & $3.66 \mathrm{~mm} \pm 0.76$ \\
Hymenelobium petraeum & Staphylococcus aureus & $4.0 \mathrm{~mm} \pm 0.5$ \\
Ciprofloxacin & & $3.66 \mathrm{~mm} \pm 0.57$ \\
& Gram negative bacteria & $9 \mathrm{~mm} \pm 0$ \\
Hymenelobium petraeum & Salmonella enterica ser. Typhi & $7 \mathrm{~mm} \pm 0.26$ \\
Ciprofloxacin & & $10 \mathrm{~mm} \pm 0$ \\
Hymenelobium petraeum & Enterococcus faecalis & $5 \mathrm{~mm} \pm 0.1$ \\
Ciprofloxacin & & $11 \mathrm{~mm} \pm 0$ \\
Pentaclethra macrolaba & & $3.96 \mathrm{~mm} \pm 0.15$ \\
Ptychopetalum olacoides & Klebsiella ozanae & $9,25 \mathrm{~mm} \pm 0.35$ \\
Ciprofloxacin & & $8 \mathrm{~mm} \pm 1.4$ \\
Pentaclethra macrolaba & Acinetobacter baumannii & $5.76 \mathrm{~mm} \pm 0.25$ \\
Ptychopetalum olacoides & & $4.9 \mathrm{~mm} \pm 0.14$ \\
Ciprofloxacin & & $11 \mathrm{~mm} \pm 0$ \\
Hymenelobium petraeum & Yeast & $11.9 \mathrm{~mm} \pm 0.1$ \\
Ciprofloxacin & Candida albicans & $13.63 \mathrm{~mm} \pm 0.32$ \\
\hline
\end{tabular}




\section{Conclusions}

Considering that $9 \mathrm{~mm}$ halo inhibition produced by the commercial antibiotic ciproflacin (test control) over Staphylococcus aureus represents 100\% of antibacterial activity, the botanic aqueous extracts of Vatairea guianensis had $44.4 \%(4 \mathrm{~mm})$ activity while Symphonia globulifera and Hymenelobium petraeum (3.66 mm) 40.6\%. In the same way, the botanic aqueous extract of Pentaclethra macrolaba did not show any activity over Staphylococcus aureus, but inhibited the growth of Klebsiella ozaenae and Acinetobacter baumannii, representing 49.5\% (3.96 mm halo) and 52.4\% (5.76 $\mathrm{mm}$ halo) respectively, of the ciprofloxacin halo produced $(8 \mathrm{~mm}$ and $11 \mathrm{~mm}$ halo respectively). Also, the botanic aqueous extract of Ptychopetalum olacoides inhibited exclusively the growth of Klebsiella ozaenae and Acinetobacter baumannii, producing halos higher than 100\% (9.25 $\mathrm{mm}$ halo) and $45.4 \%$ (5 mm halo) respectively, when compared to halos produced by ciprofloxacin $(8$ and $11 \mathrm{~mm})$. Of all aqueous botanical extract tested, Hymenelobium petraeum was the most active, exhibiting also activity against Salmonella enterica ser. Typhi (7 mm halo), Candida albicans (11.9 mm halo) and Enterococcus faecalis (5 $\mathrm{mm}$ halo) representing $70 \%, 87.3 \%$ and $45.5 \%$ respectively, when compared to ciprofloxacin activity $(10 \mathrm{~mm}, 13.63 \mathrm{~mm}$ and $11 \mathrm{~mm}$ halo respectively) (Table 1 ).

The preliminary results obtained in these experiments pave the road to explore the potential development of new compounds to be launched in the pharmaceutical market filling a tremendous gap, as day by day new multiresistant microorganisms emerges. All plants here assayed present medicinal properties being commonly utilized by local people in the Amazon region. Therefore it is much easier to confirm the new curative properties found, as the proper use of these plants is for general purposes. Likewise, the dried pieces of Hymenelobium petraeum's bark are utilized to prepare syrup to treat throat inflammation by people of African ancestry in "quilombolas", small villages reminiscents of African slaves in the Amapa state. Despite the medicinal properties of Hymenelobium petraeum, it is well-known the utilization of the wood to build houses and to manufacture furnitures due to its spoil resistance, hardness, and beautiful colour. Seeds of Vatairea guianensis found floating in the innumerous rivers crossing the Amapa state, are collected by local people to prepare an unguent to use for dermatological mycosis. The latex extracted from Symphonia globulifera is utilized by the Amazonian natives for the treatment of arthritis, despite the wood of this plant be utilized for house construction and furniture manufacture. In spite of all folklore of these plants, many of them are under the risk of extinction because of the economic value represented by the products obtained from these plants. Therefore, the domestication and rational utilization of these plants are urgent and demand a considerable effort of scientists and government.

\section{Competing interest}

The authors declare that they have no competing interests.

\section{Authors' contribution}

ECG da M and RMB carryed out the phytohemical experiments. AAO, VYKS and POMJ realized the microbiological assays. JFOS and MCAG collected and identified the botanical specimens. LIBK designed the experiments and wrote the manuscript. All authors read and approved the final manuscript.

\section{Acknowledgments}

This research work was partially funded by the University of Brasilia and the Brazilian National Council of Research and Tecnnology/CNPq. The students, AAO, VYKS and ECGM, received scholarships from CNPq and CAPES, in the programs of Scientific initiation and Graduate Program in Animal Health and Animal Biology. We are indebted to Dr. Ernesto Hofer from Oswaldo Cruz Institute Foundation for Microorganisms' donation.

\section{Author details}

${ }^{1}$ Laboratory of Bioprospection, University of Brasília, University Campus Darcy Ribeiro, Asa Norte, Brasília, DF, Brazil. ²Brazilian Agricultural Research Corporation/Amapá, Rod. J K, 05 km, number 2600, University District, Macapá, AP, Brazil. ³mapa State University, Presidente Vargas Avenue, number 650, Center, Macapá, AP, Brazil. ${ }^{4}$ Federal University of Amapá, Rod Juscelino Kubitschek, KM-02, Jardim Marco Zero, Macapá, AP, Brazil.

Received: 24 April 2013 Accepted: 19 July 2013

Published: 5 August 2013

\section{References}

Alves DS (2008) Taking things public: a contribution to address human dimensions of environmental change. Philos Trans R Soc Lond B Biol Sci 363:1903-1909

Araújo NRR (2010) Avaliação in vitro da atividade antimicrobiana de extratos vegetais sobre microorganismos relacionados a lesão de mucosite oral. Federal University of Pará, Dissertation

Basso LA, da Silva LH, Fett-Neto AG, de Azevedo WF Jr, Moreira Ide S, Palma MS, Calixto JB, Astolfi Filho S, Dos Santos RR, Soares MB, Santos DS (2005) The use of biodiversity as source of new chemical entities against defined molecular targets for treatment of malaria, tuberculosis, and T-cell mediated diseases--a review. Mem Inst Oswaldo Cruz 100:475-506

Benko-Iseppon AM, Crovella S (2010) Ethnobotanical bioprospection of candidates for potential antimicrobial drugs from Brazilian plants: state of art and perspectives. Curr Protein Pept Sci 11:189-194

Bezerra FPCA, Silva ICR, Gonçalves MCA, Oliveira LO, Segovia JFO, Silveira D, Carvalho JCT, Kanzaki LIB (2010) Growth inhibition of Lactuca sativa by crude extracts of amazonian plants Stryphnodendron adstringens, Carapa guianensis and Ouratea hexasperma, 29th edn, Modern directions of theoretical and applied researches, 2010. Modern directions of theoretical and applied researches, Odessa, pp 18-29

Brothwell DR (1967) The Amerindians of Guyana: a biological review. Eugen Rev 59:22-45

Correia AF, Segovia JFO, Gonçalves MCA, Oliveira LO, Silveira D, Carvalho JCT, Kanzaki LIB (2008) Amazonian plant crude extract screening for activity against multidrug-resistant bacteria. Eur Rev Med Pharmacol Sci 12:369-380

Correia AF, Segovia JFO, Bezerra RM, Gonçalves MCA, Ornelas SS, Silveira D, Carvalho JCT, Diniz SPSS, Kanzaki LIB (2010) Aerobic and facultative microorganisms isolated from corroded metallic structures in a hydroeletric power unit in the Amazon region of Brazil. Air, Soil and Water Research 3:113-121

da Silva JO, Fernandes RS, Ticli FK, Oliveira CZ, Mazzi MV, Franco JJ, Giuliatti S, Pereira PS, Soares AM, Sampaio SV (2007) Triterpenoid saponins, new metalloprotease snake venom inhibitors isolated from Pentaclethra macroloba. Toxicon 50:283-291 
Dionisi HM, Lozada M, Olivera NL (2012) Bioprospection of marine microorganisms: biotechnological applications and methods. Rev Argent Microbiol 44:49-60

Dr. Duke's Phytochemical and Ethnobotanical Databases (2012) http://www.arsgrin.gov/cgi-bin/duke/ethnobot.pl?Vatairea\%20guianensis

Hancock RE, Nijnik A, Philpott DJ (2012) Modulating immunity as a therapy for bacterial infections. Nat Rev Microbiol 10:243-254

Howes MJ, Houghton PJ (2012) Ethnobotanical treatment strategies against Alzheimer's disease. Curr Alzheimer Res 9:67-85

Mata ECG (2011) Avaliação de Atividade Antiretroviral de Plantas Amazônicas Utilizando como. Modelo o Vírus da Imunodeficiência Símia. Dissertation, University of Brasilia, Available at http://repositorio.bce.unb.br/bitstream/ 10482/9185/3/2011_ElidaCleyseGomesdaMata.pdf

Mendes FR, Carlini EA (2007) Brazilian plants as possible adaptogens: an ethnopharmacological survey of books edited in Brazil. J Ethnopharmacol 109:493-500

Oliveira LZ, Cesarino F, Pantoja TF, Môro FV (2010) Aspectos morfológicos de frutos, sementes, germinação e plântulas de Hymenolobium petraeum. Cienc Rural 40:1732-1740

Segovia JFO, Oliveira VLO, Gonçalves MCA, Resck IS, Silva CAM, Silveira D, Gavrilov AV, Gavrilova LA, Kanzaki LIB (2011) Botanical characterization, geographical distribution and phytochemistry analysis of Manilkara huberi (Ducke) Stanhl autochtonous in Amapá State, Brazil. Proceedings of the National Academy of Sciences of Belarus/Series of Biological Sciences 2:30-40

Vieira IC, Toledo PM, Silva JM, Hiquchi H (2008) Deforestation and threats to the biodiversity of Amazonia. Braz J Biol 68:949-956

doi:10.1186/2193-1801-2-371

Cite this article as: Oliveira et al: Antimicrobial activity of amazonian medicinal plants. SpringerPlus 2013 2:371.

\section{Submit your manuscript to a SpringerOpen ${ }^{\circ}$ journal and benefit from:}

- Convenient online submission

- Rigorous peer review

- Immediate publication on acceptance

- Open access: articles freely available online

- High visibility within the field

- Retaining the copyright to your article

Submit your next manuscript at $\gg$ springeropen.com 